\title{
ОГРАНИЧЕНИЯ ПРАВ И СВОБОД ГОСУДАРСТВЕННЫХ СЛУЖАЩИХ В РЕШЕНИЯХ КОНСТИТУЦИОННОГО СУДА РОССИЙСКОЙ ФЕДЕРАЦИИ
}

\begin{abstract}
Аннотация: В статье указывается, что государство при решении возложенных на него обществом задач, связанных с обеспечением безопасности граждан и государства, защиты конституционного строя, вправе допускать определённые ограничения конституционных прав и свобод человека и гражданина. Формулируется определение ограничения прав и свобод человека и гражданина. Рассматриваются вопросы ограничения прав и свобод государственных служащих в Российской Федераџии, отмечается, что установление ограничений прав лиц, поступающих на государственную службу, служит обеспечению эффективной профессиональной деятельности по исполнению полномочий государственных органов, установлению препятствий возможному злоупотреблению государственных служащих, а также, что указанные ограничения являются одним из способов противодействия коррупщии. Анализируется правовая позиция Конституционного Суда Российской Федерации относительно правомерности ограничения прав и свобод государственных служащчих, формулируется универсальная правовая позиция Конституционного Суда России по этому вопросу, согласно которой само по себе установление для государственных служащих ограничений и запретов, обусловленньх прохождением государственной службы, допустимо, но в конституционно значимых ичелях.

Abstract: The article contains references to the fact that the state is allowed to establish some limitations to human rights and basic freedoms of individuals and citizens in order to achieve the purpose which is set for it by the society, that is, to guarantee security of citizens and state. The author formulates a definition for the limitations to basic human rights and freedoms of individuals and citizens. He analyzes the issues of limitations of rights and freedoms of persons in state service in the Russian Federation, noting that limitations for the persons joining state service serves the purpose of guaranteeing efficient professional activities in the spheres of competence of state bodies, and precludes possible abuse of rights by the servants, as well as, serves as one of the means of fighting corruption. The author analyzes the legal position of the Constitutional Court of the Russian Federation on the lawfulness of limitations of rights and freedoms of state servants, and formulates an universal position of the Constitutional Court of the Russian Federation on this issue, under which the limitations and prohibitions for the state servants due to their state service are acceptable for constitutionally valuable goals.
\end{abstract}

Ключевые слова: Юриспруденция, права, свободы, ограничение прав и свобод, противодействие коррупции, государственная служба, государственный служащий, Конституциионый Суд, судебная власть, правовые позиции Keywords: jurisprudence, rights, freedoms, limitations of rights and freedoms, fighting corruption, state service, state servant, Constitutional Court, judicial power, legal positions.

озможность ограничения прав и свобод человека и гражданина, установление оснований, пределов такого ограничения являются наиболее актуальными аспектами проблематики регулирования, реализации и защиты закреплённых в Конституции Российской Федерации прав человека и гражданина. Надлежащее их решение имеет важное значение как для формирования теории прав человека в России, так и для развития государственно-правовой практики ${ }^{1}$.

\footnotetext{
${ }^{1}$ Агеев В.Н. Конституционные ограничения основных прав и свобод личности в Российской Федерации: теория, история, практика / В.Н. Агеев. - Казань : Изд-во КГУ, 2006. - 148 с.
}

Не вызывает сомнений, что государство при решении возложенных на него обществом задач, связанных с обеспечением безопасности граждан и государства, защиты конституционного строя, вправе допускать определённые ограничения конституционных прав и свобод человека и гражданина. Подобные шаги есть цивилизованный способ регулирования меры свободы в обществе. Однако здесь недопустимы злоупотребления и волюнтаризм. Именно поэтому в большинстве стран мира законодательство, допуская ограничения прав и свобод личности, чётко регламентирует основания, пределы и порядок их применения 2 .

\footnotetext{
2 Принципы, пределы, основания ограничения прав и свобод человека по российскому законодательству и международному праву.
} 
Конституция России впервые установила универсальный в смысле распространения на законодательную, исполнительную и судебную власть принцип: «права и свободы человека и гражданина могут быть ограничены только федеральным законом и только в той мере, в какой это необходимо в целях защиты основ конституционного строя, нравственности, здоровья, прав и законных интересов других лиц, обеспечения обороны страны и безопасности государства» (часть 3 статьи 55 Конституции Российской Федерации ${ }^{3}$.

Таким образом, определение границ допустимого ограничения основных прав и свобод в силу содержащейся в Конституции отсылки к федеральному закону относится к полномочиям законодателя, однако он не свободен в своих решениях. Соответствие этих границ установленным Конституцией критериям может быть предметом судебной проверки, имея при этом в виду, что такие ограничения должны быть соразмерны конституционным целям ограничений, и соответствовать характеру и природе отношений государства и человека.

Объектом анализа настоящей статьи и является проблема ограничения прав и свобод государственных служащих в Российской Федерации, а также вопросы правомерности подобных ограничений, которые неоднократно становились предметом судебной проверки судебного органа конституционного контроля Российской Федерации - Конституционного Суда.

Уяснение вопросов связанных с конституционным ограничением прав и свобод государственных служащих в Российской Федерации невозможно без теоретико-правового осмысления данной проблемы, без определения базового понятия - понятия ограничения прав и свобод личности в целом.

Наиболее точную трактовку, исходя из определений ограничения прав и свобод, предлагаемых различными учёными, с учётом специфики Конституции Российской Федерации как правового акта особого рода и концепции свободы личности, закреплённой Основным Законом России, на наш взгляд предлагает А. А. Подмарев. Согласно его точке зрения «ограничение права (свободы) человека (гражданина) - это установленные законодательством пределы (границы) реализации (осуществления) человеком (гражданином) прав (свобод), выражающееся в запретах, вторжениях, обязанностях, ответственности, существование

«Круглый стол» журнала «Государство и право» // Государство и право. - 1998. - № 8. - С. 41.

${ }^{3}$ Конституция Российской Федерации : принята всенародным голосованием 12 декабря 1993 г. // Российская газета. - 1993. - 25 дек. которых детерминировано (предопределено) необходимостью защиты конституционно признаваемых ценностей, и назначением которых является обеспечение необходимого баланса между интересами личности, общества и государства» ${ }^{4}$.

Анализ федерального законодательства позволяет выделить из института ограничений прав и свобод личности ограничения, по признаку особого статуса субъекта, то есть когда специфический субъективный состав объективно, по мнению законодателя, предполагает возникновение конституционных случаев правомерного ограничения прав и свобод, предусмотренных частью 3 статьи 55 Конституции Российской Федерации. К такому роду ограничений прав и свобод относятся, в частности, ограничения прав и свобод государственных служащих.

Установление ограничений прав лиц, поступающих на государственную службу, служит обеспечению эффективной профессиональной деятельности по исполнению полномочий государственных органов, установлению препятствий возможному злоупотреблению государственных служащих, гарантированию осуществления служащими гражданских прав и др. ${ }^{5}$.

По мнению А. В. Малько, прообраз идеи правового государства возник по сути дела как противоядие от злоупотреблений политической властью, как реакция на произвол, деспотизм, тиранию. Именно в связывании, ограничении правом государства и заключается сущность правового государства. Правовые ограничения необходимы именно для того, чтобы недостатки властной личности не превратились в пороки государственной власти. Вот почему можно сказать, что правом ограничиваются не собственно управляющие воздействия со стороны государственных структур на личность, а лишь препятствия, вредные возмущающие факторы, необоснованные и противоправные ущемления интересов граждан ${ }^{6}$.

Регламентируя правовое положение государственных служащих, порядок поступления на государственную службу и её прохождения, государство вправе устанавливать в этой сфере и особые правила.

\footnotetext{
${ }^{4}$ Подмарев $A$. A. Конституционные основы ограничения прав и свобод человека и гражданина в Российской Федерации : дис. ... канд. юрид. наук / А. А. Подмарев. - Саратов, 2001. - С. 44.

${ }^{5}$ См.: Комментарий к Федеральному закону «О государственной гражданской службе Российской Федерации» и законодательству о гражданской службе зарубежных государств / отв. ред. А. Ф. Ноздрачев. - М. : МЦФЭР, 2005. - С. 128.

${ }^{6}$ Малько А. В. Стимулы и ограничения в праве / А. В. Малько. - М.: Юристъ, 2004. - С. 230 - 231.
} 
DOI: $10.7256 / 1811-9018.2013 .13 .7201$

При цитировании этой статьи сноска на ооі обязательна

\section{Право и политика $13(168) \cdot 2013$}

Установление таких правил (специальных требований) обусловлено задачами, принципами организации и функционирования государственной службы, целью обеспечения поддержания высокого уровня её отправления (в том числе за счёт обновления и сменяемости управленческого персонала), особенностями деятельности лиц, исполняющих обязанности по государственной должности государственной службы

С формированием законодательства о государственной службе встала проблема ограничений прав и свобод - в первую очередь, установленных в Конституции Российской Федерации, - лиц, поступающих на государственную службу или состоящих на ней. В литературе отмечается, что правовой режим для государственного служащего выступает сугубо ограничительным, что связано с установлением правового режима ограничений для государственных структур в целом ${ }^{8}$.

Установление ограничений и запретов на государственной службе соответствует международным правовым актам. Так, в соответствии с пунктом 8 Международного кодекса государственных должностных лиц, принятого 12 декабря 1996 года, государственные должностные лица, в соответствии с занимаемым ими служебным положением и как это разрешено или требуется законом и административными положениями, выполняют требования об объявлении или сообщении сведений о личных активах и обязательствах, а также, по возможности, сведения об активах и обязательствах супруга (супруги) и (или) иждивенцев. Кроме того, во Всеобщей декларации прав человека 1948 года ${ }^{9}$, допускаются ограничения прав и свобод, которые устанавливаются законом исключительно с целью обеспечения должного признания и уважения прав и свобод других людей и удовлетворения справедливых требований морали, общественного порядка и общего благосостояния в демократическом обществе. Кроме того,

\footnotetext{
${ }^{7}$ По запросу группы депутатов Государственной Думы о проверке конституционности положений статьи 25 Федерального закона «Об основах государственной службы Российской Федерации», статьи 43 Федерального закона «О прокуратуре Российской Федерации», статьи 14 Федерального конституционного закона «О судебной системе Российской Федерации» и статьи 20.1 Федерального закона «Об основах муниципальной службы в Российской Федерации»: определение Конституционного Суда Российской Федерации от 3 октября 2002 года // Собрание законодательства Российской Федерации. - 2003. - № 12. - Ст. 1174.

${ }^{8}$ Малько А. В. Указ. соч. - С. 239.

${ }^{9}$ Всеобщая декларация прав человека: принята Генеральной Ассамблеей ООН 10 декабря 1948 года // Российская газета. 1995. - 5 апр.
}

вопросы правомерности ограничения прав и свобод государственных служащих нашли своё отражение в этических международных стандартах служебного поведения госслужащих, изложенных в документах Организации Объединённых Наций и Совета Европы, таких как Международный кодекс поведения государственных должностных лиц ${ }^{10}$, Кодекс поведения должностных лиц по поддержанию правопорядка ${ }^{11}$, Руководящие принципы для эффективного осуществления Кодекса поведения должностных лиц по поддержанию правопорядка ${ }^{12}$ и др.

Конституционные положения, касающиеся ограничений прав и свобод государственных служащих в России конкретизируются значительным количеством законодательных актов, регулирующих порядок прохождения того или иного вида государственной службы, такими как федеральные законы

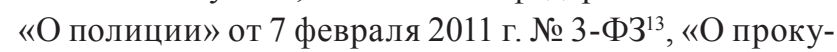
ратуре Российской Федерации» от 17 января 1992 года № 2202-1 ${ }^{14}$, «О статусе военнослужащих» от 27 мая 1998 года № 76-Ф3 ${ }^{15}$, «О статусе судей в Российской Федерации» от 26 июня 1992 года № 3132-1'16, «О службе в таможенных органах Российской Федерации» от 21 июля 1997 года № 114-Ф3'7 и др. Однако, свою особую детализацию эти нормы получили в Федеральном законе «О государственной

\footnotetext{
${ }^{10}$ Международный кодекс поведения государственных должностных лиц (Принят 12 декабря 1996 г. Резолюцией 51/59 на 82-ом пленарном заседании 51-ой сессии Генеральной Ассамблеи ООН) [Электронный ресурс]. - Доступ из справ.-правовой системы «Консультант Плюс».

${ }^{11}$ Кодекс поведения должностных лиц по поддержанию правопорядка (Принят 17 декабря 1979 г. Резолюцией 34/169 на 106-ом пленарном заседании Генеральной Ассамблеи ООН) // Международная защита прав и свобод человека. Сборник документов. - М.: Юридическая литература, 1990. - С. 319 - 325.

12 Руководящие принципы для эффективного осуществления Кодекса поведения должностных лиц по поддержанию правопорядка (Приняты 24 мая 1989 г. Резолюцией 1989/61 на 15 -ом пленарном заседании Экономического и Социального Совета ООН) [Электронный ресурс]. - Доступ из справ.-правовой системы «Консультант Плюс».

${ }^{13}$ Собрание законодательства Российской Федерации. - 2011. № 7. - Ст. 900.

${ }^{14}$ Ведомости Съезда народных депутатов Российской Федерации и Верховного Совета Российской Федерации. - 1992. - № 8. - Ст. 366.

${ }^{15}$ Собрание законодательства Российской Федерации. - 1998. № 22. - Ст. 2331.

${ }^{16}$ Ведомости Совета народных депутатов и Верховного Совета Российской Федерации. - 1992. - № 30. - Ст. 1792.

${ }^{17}$ Собрание законодательства Российской Федерации. - 1997. № 30. - Ст. 3586 .
} 
гражданской службе Российской Федерации» от 27 июля 2004 года № 79-Ф318.

Как уже отмечалось ранее, к лицам, поступающим на государственную службу, предъявляются специальные требования.

В число квалификационных требований к должностям гражданской службы входят требования к уровню профессионального образования, стажу гражданской службы или стажу (опыту) работы по специальности, профессиональным знаниям и навыкам, необходимым для исполнения должностных обязанностей, принадлежности к гражданству и др.

Кроме того, ряд законодательных актов, регулирующих деятельность отдельных категорий государственных служащих, содержит и иные требования к кандидатам. Так, например, на службу в полицию не могут быть приняты граждане, имеющие либо имевшие судимость, а также граждане неоднократно в течение года, предшествовавшего дню поступления на службу в полицию, подвергавшиеся в судебном порядке административному наказанию за совершённые умышленно административные правонарушения ${ }^{19}$.

К кандидату на должность судьи, кроме всех прочих требований, применяются и дополнительные. Так, судьёй может быть гражданин Российской Федерации не имеющий гражданства иностранного государства либо вида на жительство или иного документа, подтверждающего право на постоянное проживание гражданина Российской Федерации на территории иностранного государства; не признанный судом недееспособным или ограниченно дееспособным; не состоящий на учёте в наркологическом или психоневрологическом диспансере в связи с лечением от алкоголизма, наркомании, токсикомании, хронических и затяжных психических расстройств; не имеющий иных заболеваний, препятствующих осуществлению полномочий судьи ${ }^{20}$.

Следует, кроме всего прочего, отметить, что ограничения прав и свобод государственных служащих являются, кроме всего прочего, одним из эффективных средств противодействия коррупции. Этот антикоррупционный механизм, предполагает информационную

${ }^{18}$ Собрание законодательства Российской Федерации. - 2004. № 31. - Ст. 3215 .

${ }^{19}$ О полиции : федеральный закон от 7 февраля 2011 г. № 3-Ф3 // Собрание законодательства Российской Федерации. - 2011. - № 7. - Ст. 900.

${ }^{20}$ О статусе судей в Российской Федерации: закон Российской Федерации от 26 июня 1992 года № 3132-1 // Ведомости Совета народных депутатов и Верховного Совета Российской Федерации. - 1992. - № 30. - Ст. 1792. открытость деятельности должностных лиц государства и позволяет противодействовать совершению коррупционных преступлений.

Учитывая безусловную важность исследуемого института, остановимся на анализе правовой позиции Конституционного Суда Российской Федерации относительно вопросов правомерности (возможности) ограничения прав и свобод государственных служащих в России.

Следует отметить, что Конституционный Суд России неоднократно указывал, что специфика государственной службы Российской Федерации как профессиональной деятельности по обеспечению исполнения полномочий государственных органов предопределяет особый правовой статус государственных служащих в трудовых отношениях. Как уже отмечалось, государство вправе определять особые правила в сфере государственной службы, устанавливая определённые ограничения для своих служащих. При этом Конституционный Суд Российской Федерации признаёт установление ограничений прав государственных служащих обоснованным при наличии компенсации в виде повышенных льгот и гарантий социальной защищённости ${ }^{21}$.

Что касается нормотворчества Конституционного Суда Российской Федерации, то необходимо сказать, что в системе государственных органов современной России Конституционный Суд занимает весьма важное место и играет многоплановую и трудно переоценимую роль 22 .

В Федеральном конституционном законе от 21 июля 1994 года № 1-ФКЗ «О Конституционном Суде Российской Федерации» ${ }^{23}$ указанный институт рассматривается как судебный орган конституционного контроля, самостоятельно и независимо осуществляющий судебную власть посредством конституционного судопроизводства. Согласно ст. 6 указанного закона решения Конституционного Суда обязательны на всей территории Российской Федерации для всех представительных, испол-

\footnotetext{
${ }^{21}$ По делу о проверке конституционности абзаца 2 части седьмой статьи 19 Закона РСФСР от 18 апреля 1991 года «О милиции» в связи с жалобой гражданина В. М. Минакова : постановление Конституционного Суда Российской Федерации от 6 июня 1995 года // Собрание законодательства Российской Федерации. - 1995. № 24. - Ст. 2342.

${ }^{22}$ Марченко М. Н. Судебное правотворчество и судейское право / М. Н. Марченко. - М. : Проспект, 2011. - С. 245.

${ }^{23}$ Собрание законодательства Российской Федерации. - 1994. № 13. - Ст. 1447.
} 
DOI: $10.7256 / 1811-9018.2013 .13 .7201$

При цитировании этой статьи сноска на dоі обязательна

\section{Право и политика $13(168) \cdot 2013$}

нительных и судебных органов государственной власти, органов местного самоуправления, предприятий, учреждений, организаций, должностных лиц, граждан и их объединений.

Л. А. Ломакина подчёркивает, что не являясь законодательным органом, Конституционный Суд, тем не менее, принимает важнейшие положения, трансформирующиеся впоследствии в полноценные нормы права, а также разъясняет и толкует законодательные положения, придавая им более точный и понятный смысл ${ }^{24}$.

Возвращаясь к правовым позициям Конституционного Суда Российской Федерации относительно ограничения прав и свобод государственных служащих, необходимо отметить, что обозначенная выше позиция является устоявшейся и находит своё отражение в ряде его решений.

Так, в Постановлении Конституционного Суда Российской Федерации от 30 октября 2003 г. № 15-П указывается, что специфика государственной службы как профессиональной деятельности по обеспечению исполнения полномочий государственных органов предопределяет особый правовой статус государственных служащих. Поэтому, регламентируя правовое положение государственных служащих, порядок поступления на государственную службу и её прохождения, государство вправе устанавливать в этой сфере и особые правила (ограничения), но строго обусловленные мерами обеспечения баланса конституционно защищаемых ценностей и интересов ${ }^{25}$.

Согласно Определению Конституционного Суда Российской Федерации от 11 июля 2006 г. № 213-О конституционный принцип равенства не препятствует законодателю при осуществлении правового регулирования трудовых отношений устанавливать различия в правовом статусе лиц, принадлежащих к разным по условиям и роду деятельности категориям, в том числе вводить особые правила, касающиеся условий замещения отдельных должностей и оснований освобождения

\footnotetext{
${ }^{24}$ Ломакина Л. А. Влияние правовых позиций Конституционного Суда РФ на развитие законодательства об административной ответственности / Л. А. Ломакина // Журнал российского права. - 2012. - № 2. - C. 62.

${ }^{25}$ По делу о проверке конституционности отдельных положений Федерального закона «Об основных гарантиях избирательных прав и права на участие в референдуме граждан Российской Федерации» в связи с запросом группы депутатов Государственной Думы и жалобами граждан С. А. Бунтмана, К. А. Катаняна и К. С. Рожкова : постановление Конституционного Суда Российской Федерации от 30 октября 2003 г. № 15-П // Собрание законодательства Российской Федерации. - 2003. - № 44. - Ст. 4358.
}

от должности, если эти различия являются объективно оправданными, обоснованными и соответствуют конституционно значимым целям и требованиям ${ }^{26}$.

Такие различия, основанные на специфических (квалификационных) требованиях, связанных с определённой работой, согласно пункту 2 статьи 1 Конвенции № 111 Международной организации труда «Относительно дискриминации в области труда и занятий» ${ }^{27}$, не считаются дискриминацией (Постановление от 6 июня 1995 года № 7-П²8, определения от 1 июля 1998 года № 84-О루의 от 8 февраля 2001 года № 45-О ${ }^{30}$; от 5 июля 2001 года № 134-О ${ }^{31}$;

${ }^{26}$ По жалобе гражданина Щеренко Александра Павловича на на-
рушение его конституционных прав положениями части четвёртой
статьи 332 и пункта 3 статьи 336 Трудового кодекса Российской
Федерации : определение Конституционного Суда Российской Фе-
дерации от 11 июля 2006 г. № $213-\mathrm{O} / /$ Собрание законодательства дерации от 11 июля 2006 г. № 213-О // Собрание законо
Российской Федерации. - 2006. - № 41. - Ст. 4285.

27 Относительно дискриминации в области труда и занятий: конвенция № 111 Международной организации труда (принята в г. Женеве 25 июня 1958 г. на 42-ой сессии Генеральной конференции МОТ) // Ведомости Верховного Совета СССР. - 1961. - № 44. - Ст. 448.

${ }^{28}$ По делу о проверке конституционности абзаца 2 части седьмой статьи 19 Закона РСФСР от 18 апреля 1991 года «О милиции» в связи с жалобой гражданина В. М. Минакова : постановление Конституционного Суда Российской Федерации от 6 июня 1995 года // Собрание законодательства Российской Федерации. - 1995. - № 24. - Ст. 2342.

${ }^{29}$ Об отказе в принятии к рассмотрению запроса Верховного Суда Российской Федерации о проверке конституционности подпункта 1 пункта 2 и пункта 3 статьи 25 Федерального закона «Об основах государственной службы Российской Федерации» : определение Конституционного Суда Российской Федерации от 1 июля 1998 г. № 84-О (текст Определения официально опубликован не был) [Электронный ресурс]. - Доступ из справ.-правовой системы «Консультант Плюс».

${ }^{30}$ По запросу Люберецкого городского суда Московской области о проверке конституционности положений пункта 1 статьи 20.1 Федерального закона «Об основах муниципальной службы в Российской Федерации» и подпункта 4 пункта 3 статьи 41 Закона Московской области «О муниципальных должностях и муниципальной службе в Московской области» : определение Конституционного Суда Российской Федерации от 8 февраля 2001 г. № 45-О (текст Определения официально опубликован не был) [Электронный ресурс]. - Доступ из справ.-правовой системы «Консультант Плюс».

${ }^{31}$ По запросу Суда Чукотского автономного округа о проверке конституционности положений статьи 43 Федерального закона «О прокуратуре Российской Федерации» и по жалобе гражданина Соковца Владимира Платоновича на нарушение этими положениями его конституционных прав : определение Конституционного Суда РФ от 5 июля 2001 г. № 134-О // Вестник Конституционного Суда Российской Федерации. - 2002. - № 1. 
3 октября 2002 года № 233-О 32; 19 апреля 2007 года № 266-O-O $\mathrm{O}^{33}$ ).

Рассматривая жалобу гражданки Д. П. Тесленко на неконституционность некоторых положений Федерального закона от 27 июля 2004 года № 79-Ф3 «О государственной гражданской службе Российской Федерации» ${ }^{34}$, Конституционный Суд России указал, что установление особого правового статуса гражданских служащих осуществляется федеральным законодателем, который посредством специального правового регулирования вправе определять для данной категории лиц соответствующие права, обязанности, ограничения и гарантии с учётом специфики задач, принципов организации и функционирования государственной гражданской службы.

Поскольку государственная гражданская служба представляет собой особую форму реализации права на свободное распоряжение своими способностями к труду, специальные нормы, которые регулируют служебные отношения лиц, замещающих должности государственной гражданской службы, могут отличаться от норм, регламентирующих отношения, возникающие в процессе реализации указанного права в иных формах (в частности, путём заключения трудового договора) ${ }^{35}$.

32 По запросу группы депутатов Государственной Думы о проверке конституционности положений статьи 25 Федерального закона «Об основах государственной службы Российской Федерации», статьи 43 Федерального закона «О прокуратуре Российской Федерации», статьи 14 Федерального конституционного закона «О судебной системе Российской Федерации» и статьи 20.1 Федерального закона «Об основах муниципальной службы в Российской Федерации» : определение Конституционного Суда Российской Федерации от 3 октября 2002 г. № 233-О // Собрание законодательства Российской Федерации. - 2003. - № 12. - Ст. 1174.

${ }^{33}$ Об отказе в принятии к рассмотрению жалобы гражданина Курбанова Магомедшарипа Шариповича на нарушение его конституционных прав положениями пунктов 1 и 2 статьи 43 Федерального закона «О прокуратуре Российской Федерации» и Инструкции о порядке прекращения (продления) службы в органах и учреждениях прокуратуры работников, достигших предельного возраста : определение Конституционного Суда Российской Федерации от 19 апреля 2007 г. № 266-О-О (текст Определения официально опубликован не был) [Электронный ресурс]. - Доступ из справ.правовой системы «Консультант Плюс».

${ }^{34}$ Собрание законодательства Российской Федерации. - 2004. № 31. - Ст. 3215 .

${ }^{35}$ Об отказе в принятии к рассмотрению жалобы гражданки Тесленко Дины Павловны на нарушение её конституционных прав пунктом 8 части 1 и частью 2 статьи 37 Федерального закона «О государственной гражданской службе Российской Федерации» : определение Конституционного Суда Российской Федерации от 2 апреля 2009 г. № 472-О-О (текст Определения официально опубликован не был) [Электронный ресурс]. - Доступ из справ.правовой системы «Консультант Плюс».
Кроме того, Конституционный Суд России подчёркивает тот факт, что реализуя право на свободное распоряжение своими способностями к труду путём поступления на государственную службу, гражданин добровольно избирает профессиональную деятельность, занятие которой предполагает наличие определённых ограничений в осуществлении им конституционных прав и свобод ${ }^{36}$.

Обобщив вышеизложенное представляется возможным сформулировать некую универсальную правовую позицию Конституционного Суда России относительно исследуемого института: само по себе установление для государственных служащих ограничений и запретов, обусловленных прохождением государственной службы, допустимо, если оно согласуется с основными целями правового регулирования государственной службы в Российской Федерации как социальном правовом государстве, отвечает законным интересам, связанным с её организацией и эффективным функционированием, и не выходит за рамки возможных ограничений конституционных прав и свобод человека и гражданина в конституционно значимых целях. Указанная позиция в полной мере соответствует Конституции Российской Федерации.

\section{Библиография:}

1. Авакьян С.А. Конституция России : природа, эволюция, современность / С.А. Авакьян. - М. : Рос. юрид. изд. дом, 1997.

2. Агеев В. Н. Конституционные ограничения основных прав и свобод личности в Российской Федерации: теория, история, практика / В.Н. Агеев. - Казань : Изд-во КГУ, 2006.

3. Комментарий к Федеральному закону «О государственной гражданской службе Российской Федерации» и законодательству огражданской службезарубежных государств / отв. ред. А. Ф. Ноздрачев. -М. : МЦФЭР, 2005.

4. Ломакина Л. А. Влияние правовых позиций Конституционного Суда РФ на развитие законодательства об административной ответственности / Л. А. Ломакина // Журнал российского права. - 2012. - № 2.

5. Малько А. В. Стимулы и ограничения в праве / А. В. Малько. - М. : Юристь, 2004.

\footnotetext{
${ }^{36}$ По делу о проверке конституционности положений пункта 10 части 1 статьи 17 Федерального закона «О государственной гражданской службе Российской Федерации» и статьи 20.1 Закона Российской Федерации «О милиции» в связи с жалобами граждан Л. Н. Кондратьевой и А. Н. Мумолина : постановление Конституционного Суда Российской Федерации от 30 июня 2011 г. № 14-П // Собрание законодательства Российской Федерации. - 2011. - № 28. - Ст. 4261.
} 
DOI: $10.7256 / 1811-9018.2013 .13 .7201$

При цитировании этой статьи сноска на dоі обязательна

\section{Право и политика $13(168) \cdot 2013$}

6. Марченко М. Н. Судебное правотворчество и судейское право / М. Н. Марченко. - М.: Проспект, 2011.

7. Подмарев А. А. Конституционные основы ограничения прав и свобод человека и гражданина в Российской Федерации : дис. ... канд. юрид. наук / А. А. Подмарев. - Саратов, 2001.

8. Принципы, пределы, основания ограничения прав и свобод человека по российскому законодательству и международному праву. «Круглый стол» журнала «Государство и право» // Государство и право. - 1998. - № 8.

\section{References (transliteration):}

1. Avak'yan S.A. Konstitutsiya Rossii : priroda, evolyutsiya, sovremennost' / S.A. Avak'yan. - M. : Ros. yurid. izd. dom, 1997.
2. Ageev V. N. Konstitutsionnye ogranicheniya osnovnykh prav i svobod lichnosti v Rossiiskoi Federatsii: teoriya, istoriya, praktika / V.N. Ageev. - Kazan’ : Izd-vo KGU, 2006.

3. Lomakina L. A. Vliyanie pravovykh pozitsii Konstitutsionnogo Suda RF na razvitie zakonodatel'stva ob administrativnoi otvetstvennosti / L. A. Lomakina // Zhurnal rossiiskogo prava. - 2012. - № 2 .

4. Mal'ko A. V. Stimuly i ogranicheniya v prave / A. V. Mal'ko. - M. : Yurist',, 2004.

5. Marchenko M. N. Sudebnoe pravotvorchestvo i sudeiskoe pravo / M. N. Marchenko. - M. : Prospekt, 2011.

6. Podmarev A. A. Konstitutsionnye osnovy ogranicheniya prav i svobod cheloveka i grazhdanina v Rossiiskoi Federatsii : dis. ... kand. yurid. nauk / A. A. Podmarev. - Saratov, 2001. 